\title{
Algorithm Implementation Crochemore Perrin On The Dictionary Application Of Latin Terms Flora And Fauna Based On Android
}

\author{
Bobby Aris Sandy ${ }^{1}$ Paska Marto Hasugian ${ }^{2}$ \\ ${ }^{1,2}$ Informatics Engineering Study Program, STMIK Pelita Nusantara Jln, Iskandar Muda, \\ Medan, Sumatera Utara, Indonesia
}

Email:bobbyarissandy73@gmail.com,paskamarto86@gmail.com

\begin{abstract}
Searching is the process of selecting the information needed from a collection of data that already exists, data search is often also called a tablelook-up or store and retrieval information. Along with the development of technology that is now so very rapid, one of them is the Smartphone application. Smartphone applications that are currently in demand are increasing sharply, that is Android. Even though the presentation is limited to the screen, Smartphones are quite efficient for its users where the mobility is very high and affordable in all circles of society. used is the string search method. String search method is a string search process or often also called string matching. In the string matching process, there is the Crochemore perrin algorithm, which is an algorithm that factoring a pattern into two parts, namely Pattrenkiri and pattern right. This method is perfect for dictionary search applications of Latin terms flora and fauna.
\end{abstract}

Keywords - Search, String Matching, Crochemore Perrin, Dictionary of Latin Terms, Flora and Fauna, Android.

\section{Introduction}

Searching is the process of selecting information needed from a collection of data that already exists, data search is often also called a look-up table or store and retrieval information. The place for searching the data can be an array in memory, it can also be a file on external storage. If the amount of data is already so large, we need a method to get the data needed, the results of the data search can be true (data has been found) or wrong (data not found). Along with the development of today's technology is very rapid. One of them is mobile or commonly known as handphone. Mobile is an electronic device that is very close to the community. With the development of technology, this mobile equipment is able to provide and present information to the public. Nowadays Mobile has rapidly developed into a smartphone, making it easier for people to access or search for information. This is also the main reason many people use smartphones. Smartphone support is now very fast and has a variety of functions. Smartphones are currently increasing sharply in demand, namely Android. Android is a linux based operating system designed for touch screen mobile devices such as smartphones and tablet computers. Android is a new breakthrough in the field of technology today, with its ease of use and is open source making enthusiasts from this Smartphone more and more has become common. Although the presentation is limited to the screen, but the Smartphone is quite efficient for its users where the mobility is very high and affordable in all circles of society. Indonesia is an archipelago that is rich in diversity of flora and fauna. In each province there are flora and fauna that are characteristic of the area. Flora and Fauna become the provincial identity in Indonesia. In Indonesia, there are many people who know what flora and fauna are, but do not know other terms. In an effort to make learning more effective and efficient, tools are needed to introduce the diversity of flora and fauna in Indonesia by utilizing smartphone technology. Therefore a mobile application in the form of a dictionary is presented to make it easier to find information about the types of flora and fauna. As for making mobile applications in the form of a dictionary, one of the methods used in searching is the string search method. String search method is a string search process or often also called string matching (string matching or pattern matching) has become a necessity in text processing. The string algorithm is used to find one or more strings (called patterns) in collections in other strings (text). The search string problem can be divided into several steps. First, given the text that is srting that is $\mathrm{n}$ characters long. Then, given a pattern that is a string of length $m$ characters $(m<n)$ that will be searched for in the text.

\section{Theory}

\subsection{Search}

Search (searching) is a job that is often done in everyday life. There are times when a search is carried out with the aim only to find out whether the data is in a set of data or not, or maybe at other times the position of 
the data sought is needed for certain purposes, or if the appearance of the data is more than once then all positions and the frequency of their appearance displayed.

The method used for searching is a method of searching data without data placement in the form of integer data which includes:

a) Binary Search Method (Binary Search)

b) Linear / Sequential Search Method (Linear / Sequential Search)

c) Interpolation Search Method

In the search for these three methods in analyzing the algorithm, based on the level of speed in the form of the length of time required and the sequence of data in the form of ascending and descending sequences in the analysis. (Rahmaddeni, 2012: 1).

\subsection{String Matching}

String Matching is the process of finding all occurrences of queries, hereinafter referred to as sections into longer strings (text). The part is denoted by $\mathrm{x}=\mathrm{x}[0 . . \mathrm{m}-1]$ and the length is $\mathrm{m}$. The text is denoted by $\mathrm{y}=\mathrm{y}$ $[0 . . \mathrm{n}-1]$ and the length is $\mathrm{n}$. The two strings consist of a set of characters called the alphabet which are denoted by $\Sigma$ (sigma) and have a size $\sigma$ (tao). String matching is divided into two, namely exact matching and heuristic or statistical matching. Exact Matching is used to find parts that come from text words. Examples of exact matching word searches are student word searches in the phrase "I am a student" or "I am a student". The system will give the result that the first sentence uses the sentence "student" while the second sentence does not, despite the fact students and students are synonymous words. The exact matching algorithm is classified into three parts according to the search direction, namely:

a) Direction of reading from left to right. The algorithms included in this category are Brute Force, Knuth Morris and Pratt (which was later developed by Knuth Morris and Pratt).

b) Direction of reading from left right. Algortima which is included in this category are Boyer and Moore, which was later developed into the Turbo Boyer Moore algorithm, Tuned Boyer Noore and zhu Takaoka.

The reading direction specified by the programmer. The algorithm included in this category is the Colussi algorithm, Crochemore-Perrin (Riyanarto Sarno, Yeni Anistyasari, Rahimi Fitri: 2012,11).

\subsection{Crochemore-Perrin algorithm}

The Crochemore-Perrin Algorithm, which is often also called the Two Way Algorithm, or the Two-Way Algorithm was published by Maxime Crochemore and Dominique Perrin in 1991. This algorithm factored the parts into two parts, the left and the right so that the parts = the left part of the right. Face matching in this algorithm consists of two parts, first matching the right side of the character to the right, then matching the left side character from right to left. Initialization phase in this algorithm calculate a good factorization of the top left and right. If (u.v) is a factorization of a part, then a repetition in (u.v) is a word w, so that these two requirements are fulfilled.

a) $\quad w$ is the suffix from $u$ or $u$ is the suffix from $w$

b) $\mathrm{w}$ is the prefix of $\mathrm{v}$ or $\mathrm{v}$ is the prefix of $\mathrm{w}$

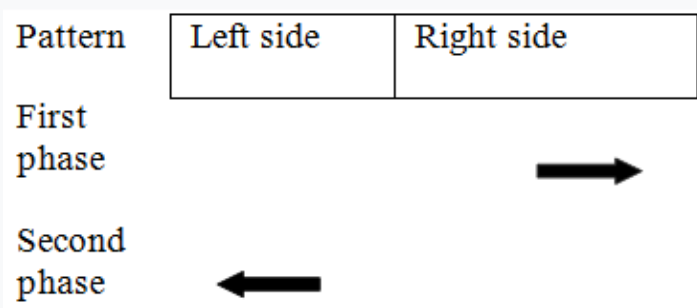

Fig.1. Pattern Distribution in the crochemore-perrin algorithm.

Algortima Crochemore-Perrin has a critical factorization (left, right) so that $\mid$ left $\mid<$ per (x) and | current section | has a minimum value. In other words, the word $w$ appears on both sides of the $u$ and $v$ chunks with possible overflow on both sides. Length of the smallest return in $(\mathrm{u}, \mathrm{v})$. Each factorization of $(\mathrm{u}, \mathrm{v})$ has at least one repetition. It can be seen easily that $1 \mathrm{r}(\mathrm{u}, \mathrm{v})|\mathrm{x}|$. The factorization $(\mathrm{u}, \mathrm{v})$ of $\mathrm{x}$ such that $\mathrm{r}(\mathrm{u}, \mathrm{v})=$ per $(\mathrm{x})$ is called from the critical factorization of $\mathrm{x}$, then in position at $|\mathrm{u}|$ at $\mathrm{x}$, the local period and the global period will be the same (Boby Hakim Lukmana, 2018: 38)

\section{Research Methods}




\subsection{Research Framework}

To assist in the preparation of this research, it is necessary to have a clear framework in its stages. The framework for the research is as follows:

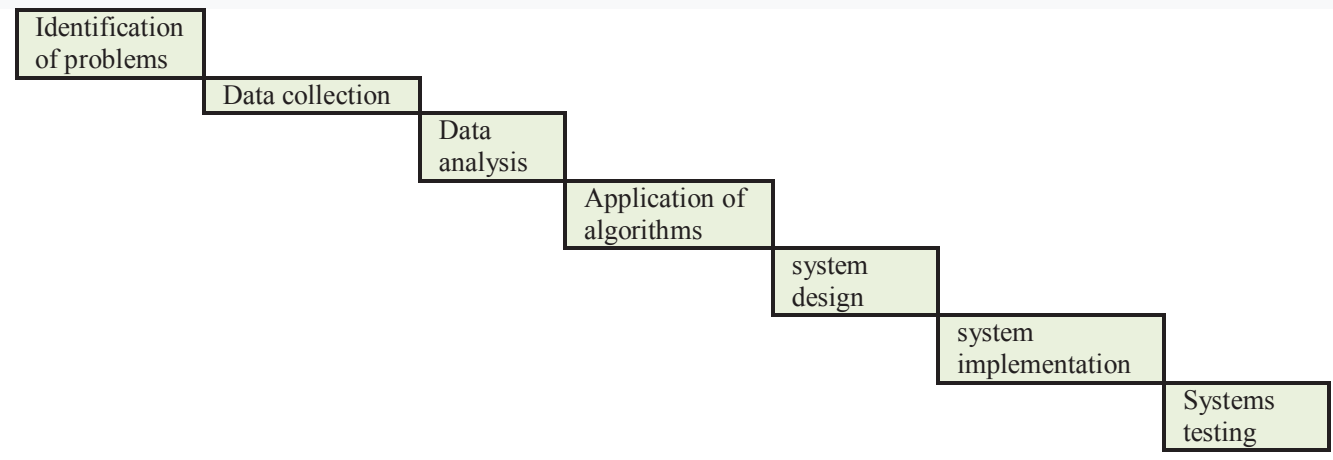

Fig.2 Research framework

\section{Analysis and Design}

\subsection{Data analysis}

Data analysis is the initial stage in system design to identify problems and needs in building a system. In designing the dictionary application Latin terms flora and fauna that will be built the researcher must know how many flora and fauna exist in the dictionary book to have the data to be processed and used in the system which will later be searched for in the dictionary application based on Android. In the dictionary book Latin terms flora and fauna there are different amounts. In the dictionary book the term flora itself has 2304 species of plants and in the dictionary book the term fauna there are 4958 species of animals.

\subsection{System Requirements Analysis}

Analysis of system requirements is a functional thing because it must be owned by a system that will be built. Analysis of system requirements can be in the form of software (software) or in terms of data storage that must be owned by a system. Syitem needs analysis that was built using the Java programming language with the platform used is Eclipse Jono. Eclipse is an IDE (Integrated Development Environment) for developing software and can be run on all platforms (platform-independent). Eclipse also requires the Android SDK (Software Development Kit) as a tool and API (Application Programming Interface) in developing applications on the Android platform using the Java programming language.

\subsection{Analysis of the Application of the Crochemore-Perrin Algorithm Method}

In applying the Crochemore-Perrin Algorithm Method in this Latin flora and fauna dictionary application, researchers used a string matching algorithm in which there is a Crochemore-Perrin algorithm as a solution to search for patterns that are used as a reference to search characters in accordance with these characters.

The following is how Crochemore-Perrin works as follows:

a) The first step of Crochrmore-Perrin begins by determining the rightmost part and the far left, as the TEXT of the search reference.

b) The second step of this algorithm determines TEXT and matches TEXT based on the right part and period.

c) Third step This algorithm determines TEXT and matches TEXT based on the left and period.

$\nabla \quad$ If the character matches the right, is marked as the initial period, and goes to the next character, then the beginning of the next search process starts from the last period.

$\otimes \quad$ If it is not suitable, slide the characters one by one and return step (a)

Following completion of the search process on the crochemore-perrin algorithm:

a) Create a search text, TEXT: PALM OIL PLANT

b) Determine the word to the left, PATTERN left $=$ COCONUT

c) Determine the right word, PATTERNright $=$ PALM

d) Determine SYMBOLS: $\mathrm{T}=$ TEXT P $=$ PERIOD X $=$ PATTERN

Settlement:

The first step is to match the right pattern with the text to be searched

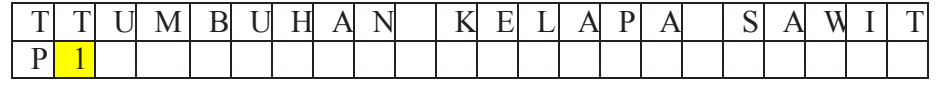


Journal of Computer Networks, Architecture and High Performance Computing

e-ISSN 2655-9102, Volume 2, No. 1, January 2020, pp 140-148

\begin{tabular}{|l|l|l|l|l|l|l|l|l|l|l|l|l|l|l|l|l|l|l|l|l|l|}
\hline $\mathrm{X}$ & $\mathrm{K}$ & $\mathrm{E}$ & $\mathrm{L}$ & $\mathrm{A}$ & $\mathrm{P}$ & $\mathrm{A}$ & & $\mathrm{S}$ & $\mathrm{A}$ & $\mathrm{W}$ & $\mathrm{I}$ & $\mathrm{T}$ & & & & & & & & & \\
\hline
\end{tabular}

Because the character 1 in the pattern with the text does not match, then slide the initial pattern by one character to the right.

\begin{tabular}{|c|c|c|c|c|c|c|c|c|c|c|c|c|c|c|c|c|c|c|}
\hline \begin{tabular}{l|l}
$\mathrm{T}$ & $\mathrm{T}$ \\
\end{tabular} & $\begin{array}{ll}\mathrm{T} & \mathrm{U} \\
\end{array}$ & $\mathrm{M}$ & \begin{tabular}{l|l}
$\mathrm{B}$ \\
\end{tabular} & $\begin{array}{lll} & H\end{array}$ & $\mathrm{~A} A$ & & & & $\mathrm{E}$ & & & $\mathrm{P}$ & A & & A & $\mathrm{W}$ & & $\mathrm{T}$ \\
\hline $\mathrm{P}$ & 1 & & & & & & & & & & & & & & & & & \\
\hline$X$ & $\mathrm{~K}$ & $\mathrm{E}$ & \begin{tabular}{l|l}
$\mathrm{L}$ & \\
\end{tabular} & \begin{tabular}{l|l}
$\mathrm{A}$ & $\mathrm{P}$ \\
\end{tabular} & $\mathrm{A}$ & & $\mathrm{S}$ & $\mathrm{A}$ & $\mathrm{W}$ & & $\mathrm{T}$ & & & & & & & \\
\hline
\end{tabular}

Because the character 1 in the pattern with the text does not match, then slide the initial pattern by one character to the right.

\begin{tabular}{|c|c|c|c|c|c|c|c|c|c|c|c|c|c|c|c|c|c|c|}
\hline $\mathrm{T}$ & $\mathrm{T}$ & $\mathrm{U} \mathrm{M}$ & & $\mathrm{U}$ & $\mathrm{H}$ & $\mathrm{A}$ & & $\mathrm{K}$ & $\mathrm{E}$ & $\mathrm{L}$ & A & $\mathrm{P}$ & $A$ & $\mathrm{~S}$ & & W & & $\mathrm{T}$ \\
\hline $\mathrm{P}$ & & 1 & & & & & & & & & & & & & & & & \\
\hline $\mathrm{X}$ & & $\mathrm{K}$ & $E$ & $\mathrm{~L}$ & A & $\mathrm{P}$ & A & $\mathrm{S}$ & $A$ & $\mathrm{~W}$ & I & $\mathrm{T}$ & & & & & & \\
\hline
\end{tabular}

Because the character 1 in the pattern with the text does not match, then slide the initial pattern by one character to the right.

\begin{tabular}{|c|c|c|c|c|c|c|c|c|c|c|c|c|c|c|c|c|c|c|}
\hline $\mathrm{T}$ & T $\mathrm{L}$ & $\mathrm{N}$ & B & $\mathrm{U}$ & $\mathrm{H}$ & & $\mathrm{N}$ & & $\mathrm{K}$ & $\mathrm{E}$ & $\mathrm{L}$ & $\mathrm{A}$ & & A & & $\mathrm{AV}$ & & \\
\hline $\mathrm{P}$ & & & 1 & & & & & & & & & & & & & & & \\
\hline$X$ & & & $\mathrm{~K}$ & $\mathrm{E}$ & $\mathrm{L}$ & $\mathrm{A}$ & $P$ & A & & $\mathrm{S}$ & $\mathrm{A}$ & $\mathrm{W}$ & II & $\mathrm{T}$ & & & & \\
\hline
\end{tabular}

Because the character 1 in the pattern with the text does not match, then slide the initial pattern by one character to the right.

\begin{tabular}{|l|l|l|l|l|l|l|l|l|l|l|l|l|l|l|l|l|l|l|l|l|l|}
\hline $\mathrm{T}$ & $\mathrm{T}$ & $\mathrm{U}$ & $\mathrm{M}$ & $\mathrm{B}$ & $\mathrm{U}$ & $\mathrm{H}$ & $\mathrm{A}$ & $\mathrm{N}$ & & $\mathrm{K}$ & $\mathrm{E}$ & $\mathrm{L}$ & $\mathrm{A}$ & $\mathrm{P}$ & $\mathrm{A}$ & & $\mathrm{S}$ & $\mathrm{A}$ & $\mathrm{W}$ & $\mathrm{I}$ & $\mathrm{T}$ \\
\hline $\mathrm{P}$ & & & & & $\mathrm{1}$ & & & & & & & & & & & & & & & & \\
\hline $\mathrm{X}$ & & & & $\mathrm{K}$ & $\mathrm{E}$ & $\mathrm{L}$ & $\mathrm{A}$ & $\mathrm{P}$ & $\mathrm{A}$ & & $\mathrm{S}$ & $\mathrm{A}$ & $\mathrm{W}$ & $\mathrm{I}$ & $\mathrm{T}$ & & & & & \\
\hline
\end{tabular}

Because the character 1 in the pattern with the text does not match, then slide the initial pattern by one character to the right.

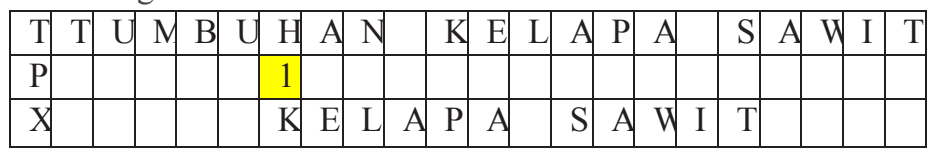

Because the character 1 in the pattern with the text does not match, then slide the initial pattern by one character to the right.

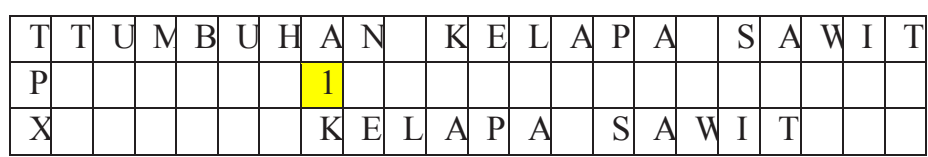

Because the character 1 in the pattern with the text does not match, then slide the initial pattern by one character to the right.

\begin{tabular}{|c|c|c|c|c|c|c|c|c|c|c|c|c|c|c|c|}
\hline $\mathrm{T}$ & $\mathrm{T}$ & U $\mathrm{N}$ & B U & $\mathrm{H} A$ & $N$ & & $\mathrm{E}$ & $\mathrm{L}$ & & $\mathrm{P}$ & A & $\mathrm{S}$ & $\mathrm{A}$ & W I & $\begin{array}{ll}\mathrm{I} & \mathrm{T} \\
\end{array}$ \\
\hline $\mathrm{P}$ & & & & & 1 & & & & & & & & & & \\
\hline $\mathrm{X}$ & & & & & $\mathrm{K}$ & $\mathrm{L}$ & A & $\mathrm{P}$ & A & & & $\mathrm{A} W$ & \begin{tabular}{l|l} 
I & 7
\end{tabular} & $\mathrm{~T}$ & \\
\hline
\end{tabular}

Because the character 1 in the pattern with the text does not match, then slide the initial pattern by one character to the right.

\begin{tabular}{|l|l|l|l|l|l|l|l|l|l|l|l|l|l|l|l|l|l|l|l|l|l|}
\hline $\mathrm{T}$ & $\mathrm{T}$ & $\mathrm{U}$ & $\mathrm{M}$ & $\mathrm{B}$ & $\mathrm{U}$ & $\mathrm{H}$ & $\mathrm{A}$ & $\mathrm{N}$ & & $\mathrm{K}$ & $\mathrm{E}$ & $\mathrm{L}$ & $\mathrm{A}$ & $\mathrm{P}$ & $\mathrm{A}$ & & $\mathrm{S}$ & $\mathrm{A}$ & $\mathrm{W}$ & $\mathrm{I}$ & $\mathrm{T}$ \\
\hline $\mathrm{P}$ & & & & & & & & & 1 & & & & & & & & & & & & \\
\hline $\mathrm{X}$ & & & & & & & & $\mathrm{K}$ & $\mathrm{E}$ & $\mathrm{L}$ & $\mathrm{A}$ & $\mathrm{P}$ & $\mathrm{A}$ & & $\mathrm{S}$ & $\mathrm{A}$ & $\mathrm{W}$ & $\mathrm{I}$ & $\mathrm{T}$ & \\
\hline
\end{tabular}

Because the character 1 in the pattern with the text does not match, then slide the initial pattern by one character to the right.

\begin{tabular}{|l|l|l|l|l|l|l|l|l|l|l|l|l|l|l|l|l|l|l|l|}
\hline $\mathrm{T}$ & $\mathrm{T}$ & $\mathrm{U}$ & $\mathrm{M}$ & $\mathrm{B}$ & $\mathrm{U}$ & $\mathrm{H}$ & $\mathrm{A}$ & $\mathrm{N}$ & $\mathrm{K}$ & $\mathrm{E}$ & $\mathrm{L}$ & $\mathrm{A}$ & $\mathrm{P}$ & $\mathrm{A}$ & $\mathrm{S}$ & $\mathrm{A}$ & $\mathrm{W}$ & $\mathrm{I}$ & $\mathrm{T}$ \\
\hline $\mathrm{P}$ & & & & & & & & & 1 & & & & & & & & & & \\
\hline $\mathrm{X}$ & & & & & & & & & $\mathrm{K}$ & $\mathrm{E}$ & $\mathrm{L}$ & $\mathrm{A}$ & $\mathrm{P}$ & $\mathrm{A}$ & $\mathrm{S}$ & $\mathrm{A}$ & $\mathrm{W}$ & $\mathrm{I}$ & $\mathrm{T}$ \\
\hline
\end{tabular}


Pattern is found, because each pattern $\neg$ and the text is complete.

In the result of the matching process, there were 9 periods (shift). Where in the crochemore-perrin algorithm the looping process occurs until the same TEXT is found with the reference TEXT.

\section{Conclusion}

Based on the analysis of the previous chapters, the researcher can draw a conclusion, where the conclusion can later be useful for the reader, so that this thesis researcher can be more useful and useful. The conclusions include the following:

a) The process of finding the Latin term flora and fauna is designed using the Crochemore Perrin algorithm. In the process of Crochemore Perrin algorithm there is text as a reference such as the sentence to be sought and pattern as the keyword to be sought. The process of searching Latin terms flora and fauna as search keywords, if there is a match then the results of the Latin terms flora and fauna that are searched will appear, but if the search process is not found, then the names of flora and fauna that you want to search have not been entered in the search database.

b) The search application makes it easy to find a dictionary of the terms Flora and Fauna that students and the general public want to know.

c) The Latin dictionary search term flora and fauna provides an alternative to be faster in finding the term Flora and Fauna wherever and whenever without having to carry a dictionary.

d) The dictionary application searches the Latin terms flora and fauna using SQLite software as databases used in collecting dictionary search data.

e) The dictionary search application for Latin flora and fauna terms was designed using Eclipse as an editor and SDK (Software Development Kit) as an application development tool on the Android platform using the Java programming language.

f) Crochemore Perrin's algorithm can be implemented in a dictionary search application for Latin-based flora and fauna terms based on Android, it can make it easier to search based on patterns (keywords).

\section{References}

[1] Rahmaddeni. Analisa Perbandingan Algoritma Pencarian(searching algoritm). Jurnal sains dan teknologi informasi, 2012, 1.42-47

[2] Sarno Riyanto, dkk. 2012," Semantic Search Pencarian Berdasarkan Konten", Andi Yogyakarta.

[3] Bobby Hakim Lukmana. Penerapan Algoritma Crochemore-perrin pada pencarian jurnal berbasis mobile. Jurnal Pelita Informatika. 17(1), 2018.39

[4] Marjito. Aplikasi Penjualan Online Berbasis Android. Jurnal Computech \& bisnis, 2016, 10(1),40-49.

[5] https://elib.unikom.ac.id/files/disk1/618-gdl-ratihfauza-30898-9-unikom_r-i.pdf

[6] Yudha Yudhanto, Ardhi wijayanto. 2018. Mudah Membuat dan Berbinis Aplikasi Android dengan AndroidStudio. Kompas Gramedia.

[7] Harni Kusniyati, dkk. Aplikasi Edukasi Budaya Toba Samosir Berbasis Android. Jurnal teknik informatika, 2016,9(1).9-18.

[8] Irwan, Perancangan Aplikasi sms Enkripsi teks menggunakan Algoritma Blok Chipper AES Berbasis Mobile pada platform Android, 2012.

[9] Rosa A.S, M.Shalahuddin. 2018. Rekayasa Perangkat Lunak. Bandung.Informatika

[10] https://repository.bsi.ac.id/index.php/unduh/item/20880/File-9-Daftar-Simbol.pdf

[11] Ahmad Iskak, Yudistinah. 2008. Bahasa Indonesia Tataran Semenjana. Erlangga.

[12] https://ilmugeografi.com/biogeografi/pengertian-flora-dan-fauna 